\title{
PROBLEMS AND OPPORTUNITIES IN HEMISPHERIC ECONOMIC DEVELOPMENT
}

\author{
Joseph C. Rovenskx* and A. Willing Patterson $\dagger$
}

The immediate concerns of hemispheric trade gain perspective when viewed in relation to the problems and opportunities faced by our government in attempting to plan, with its neighbors, a long-term economic program in the Western Hemisphere. This article will consider those problems and opportunities; it will discuss some of the complications and dangers involved in such planning, objectives and means of attaining them, machinery, and methods of approach. Its scope will be confined to our relations with the other American republics. Its treatment must be brief and general, but many of the matters touched on are developed more fully elsewhere in the symposium for which this article is to serve as introduction.

\section{I}

Simon Bolivar, the Great Liberator, held the first inter-American conference in Panama in 1826, three years after the proclamation of the Monroe Doctrine; to this conference John Quincy Adams sent representatives from the United States. Our trade with the other American republics is several centuries old, but it was not till ISgo that Bolivar's dream of an Inter-American Congress of Nations was given a permanent form with the creation of the Pan American Union.

The history of our relations with the other American republics, economic as well as political, has been marred by mistakes, the most conspicuous of which have perhaps been our own mistakes, of omission as well as of commission (including the fact that the representatives sent by Mr. Adams to Bolivar's conference arrived too late to be of much use). In addition to certain governmental actions over a period of years which were not considered as being friendly by our neighbors to the south, the activities of our business people have not always compared favorably with those of the Germans and English, who have been more painstaking in learning the language and trade customs and in getting to know the people and their habits.

\footnotetext{
* Ph.G., 1909, University of Pittsburgh; LL.D., 1939, Washington and Jefferson College. Co-Director of American Hemisphere Division, Board of Economic Warfare, and Assistant Coordinator, Office of the Coordinator of Inter-American Affairs. Vice President, Bankers' Association for Foreign Trade; Director, National Foreign Trade Council. Vice President in charge of the Foreign Department, The Chase National Bank, New York, 1928-1940. Author of numerous articles on foreign banking and commercial topics. † A.B., 1932, Graduate School of Business Adm'n, 1932-1933, Harvard University. Business economist, Commercial and Financial Division, Office of Coordinator of Inter-American Affairs since September, I94I. Previously associated with Drexel \& Co., Philadelphia.
} 
A new conception of our relationship with the other American republics, formulated over a number of years, was publicized in Mr. Roosevelt's I933 inaugural address as the "Good Neighbor" policy. The advent of war has crystallized the importance of this policy.

The present world crisis has provided us with a great opportunity to give impetus to sound long-term economic plans. Immediate problems must be attacked, but longer-term objectives reaching into the post-war period should be kept very much in mind. A major immediate problem consists of keeping the American republics supplied with the flow of goods from this country necessary to maintain their economies. We are not now able to satisfy all their wants but we must see to it that their wants are filled in the same order as defense and non-defense wants in this country. Under Secretary of State Welles voiced this policy as follows in a short-wave broadcast in Spanish in August, 194r: "I wish, however, officially to state that, so far as concerns the type of goods of which the United States is the principal or sole supplier, they will be made available on an equal basis to the people of the other American republics as liberally as they are to the people of this country." Their urgent need for certain of our goods at this time, and ours for theirs, leaves the door open for more permanent mutually beneficial trade and economic development. At the same time, we have a grave responsibility not to encourage on emergency grounds any action which, while temporarily helpful, would be injurious to the interests of our southern friends over the longer term. Assuming that the post-war world returned to what have heretofore been the usual channels of trade, how far would we be prepared to go in backing war-developed production in the other American republics against the older sources of supply? We must do some measure of planning for tomorrow while struggling with today.

Obviously a major complication in any long-term planning for the hemisphere is the fact that part of the Latin American economy is in direct competition with our own, a fact which has led many sceptics to observe that inter-American economic cooperation is a waste of time. Argentine beef, corn and wheat, Brazilian cotton, Chilean copper-world markets have seen keen competition between some of these products and our own, with a resultant strain on hemisphere solidarity. Some idea of the extent of this competition may be gathered from the following table showing the value (in millions of dollars) of major competing export surpluses in 1938:

U. S. A.

corn cotton meats suleat $\begin{array}{lllllll}\text { Latin A } & 28\end{array}$

Allied with this complication is that of surplus production as a whole. In addition to the competing products already mentioned, Latin America produces coffee, bananas, sugar and other products which do not compete with our own, but of which she has worrisome surpluses. In the past we have taken some $60 \%$ of her coffee output and about $65 \%$ of her sugar output, the exportable balance going chiefly 
to Europe, while her banana production is so large that we cannot begin to absorb it. Since Europe normally has taken about $40 \%$ of our exports and from 50 to $60 \%$ of those of the other American republics, any program based on independence from European markets implies sharp readjustments of economies within our hemisphere.

A third complicating factor is our inability to foretell post-war conditions. A plan which would be desirable under one set of future conditions might prove a boomerang if a radically different pattern developed. Such uncertainty is inherent in any long-term planning, but is doubly important where the field of effort is so large. Some of the many other complications will be alluded to later.

In formulating any long-term economic plans for the hemisphere, dangers inherent in such planning should be kept very much in mind. First, we must not forget that there is more to the world than our hemisphere. An attempt to establish a permanently self-sufficient and interdependent hemisphere which would have to hold its own in the post-war world against other trade areas would be contrary to that freedom of trade which is purportedly one of the objectives for which the democracies are struggling. The war has accentuated a trend to economic regionalism, but it is questionable how far we should go along this path. Any system of increased international cooperation after the war would be checked in its inception by the existence of a new major autarchical economic unit, hemmed in by elaborate trade restrictions of the sort which helped pave the way for the present war. For example, we have normally used about $80 \%$ of the world's export of rubber, $95 \%$ of our supply coming from Asia. If a very extensive rubber industry were built up in South America (assuming a war of many years' duration) which in post-war years had to be subsidized to enable it to compete with East Indian production, the net effect on the world economy might be the disruption of normal sound trade channels and a lowering of the standard of living. We must be very careful not to stimulate production that is going to take a nose dive after the war where the net long-term effect on the economy of the producing country or countries will be harmful.

Second, there is the danger of attempting too much. The difficulties experienced in our attempts to solve our own economic troubles, such as the agricultural surplus problem, with the huge costs attendant on some of those attempts, should dictate a humble, carefully thought out, and not too ambitious approach in tackling the more complicated and larger problems of the hemisphere.

Third, we should avoid raising false hopes on the part of our neighbors by promises which we may be unable to fulfill. Promises of this sort will tend to a net deterioration of inter-American relations.

Fourth, we should guard against the role of a hemisphere Santa Claus. In cases where we grant financial, technical and other assistance to the other countries of the hemisphere, responsibilities and contributions on their part are essential for the desired goal of cooperative action.

Fifth, we must avoid the mistake made in certain quarters after the last war of neglecting our economic relations with Other America when the emergency was over. Ambassador Winant's statement that "when the war is won for democracy, then we 
must be prepared to conquer the peace" applies forcefully to our policy in this hemisphere.

Despite the above-mentioned complications and dangers, we have pressing responsibilities as the major economic power in the hemisphere in a time of world emergency. While we do not have to, and should not, take on the whole burden resulting from the impact of the war and its aftermath on every American republic, enlightened self-interest over the longer term as well as good neighborliness, point to the common-sense wisdom of our steadily increasing economic collaboration with the other American nations. So unpredictable and rapidly changing is the world scene, that any long-term economic policy must above all be flexible. While keeping long-term objectives in mind, furthermore, concrete and immediate projects of obvious economic and social utility to the American republics should be carried out, irrespective of the outcome of the war. What should these long-term objectives be?

\section{III}

Our primary objective should be to accelerate the economic development of the other American republics to allow those larger standards of consumption which their resources would permit if properly developed. They have far greater resources than have already been developed, could usefully support a much larger population, and could raise the standard of living of a large part of their present population. A properly executed developmental program will be mutually beneficial and will feed upon itself. The expansion of desirable new production and new industry will help to stabilize employment, increase wages, and raise the standard of living and purchasing power of an important segment of the population. It has been estimated that more than half of the Latin American population of some 120 million live on family incomes of \$roo a year or less, while only a very small percentage receive as much as $\$ 1,000$. Increased purchasing power of these countries will mean not only greater capacity to buy our goods but increased trade among themselves; it will help solve the surplus problem and increase the demand for any new local production which may be developed, such as that of rubber, thereby creating new outlets for such production over the longer term. The disparity between the purchasing power of our economy and that of the other American republics is one of the most serious obstacles to an extensive and permanent two-way trade; steps to narrow this gap by increasing their purchasing power are essential and will be mutually helpful irrespective of the outcome of the war. We should work toward an economy of plenty and steadily improving living standards in the hemisphere.

The need for diversification of Latin American economies was highlighted by their vulnerability to shifts in international trade resulting from the war. When the war broke out, Central and South America were producing some $\$ 5$ billion of goods annually, of which over a quarter represented value added by manufacturing and processing industries employing about two million persons. Over a third was being exported and about one tenth (some $\$ 500$ million) was going to Continental Europe. Coffee, corn, cotton, copper, petroleum, and wool accounted for over one fourth of 
total production. Ten agricultural products accounted for half of the total exports, and half the production of these ten products was being exported. The United States, on the other hand, was exporting only $8 \%$ of its total output and the same percentage of its agricultural products. The British blockade and German continental domination inexorably closed one market after another on which the other American republics had been dependent for the wherewithal to buy vital manufactured and semifabricated materials. More than a third of their public revenues had been derived from customs duties, which fell off with the corresponding shrinkage in imports, inasmuch as Continental Europe had been an important supplier of many Latin American commercial and industrial needs. A good number of these countries were one- or two-crop countries or had only recently emerged from that stage. Their vulnerability to such a sudden shift in world trade, on the economic front and hence on the political front, was therefore serious.

The problem would have been even more grave if considerable diversification had not already been achieved since the last war, particularly during the depression years of the 1930's. In Brazil, added impetus to this diversification, chiefly industrialization, has been provided by the war. Coffee, which less than twenty years ago accounted for $74 \%$ of her total exports, now contributes only $32 \%$ of exports, though the tonnage of coffee exported has increased. Brazil, while only $3 \%$ of her arable land is cultivated, leads the world in coffee production, is second in cacao, third in corn, fifth in cotton and sugar, seventh in meat, and ninth in rice. Yet the value of her industrial production is now $20 \%$ larger than that of her total agricultural output. Argentina, Chile and other countries have also made progress toward diversification of their economies, but there is still vast room for improvement.

Other desirable objectives, allied in greater or less degree with the major objective of accelerating the development of their economies, as well as with one another, include the following:

I. Stimulation of primary production which does not compete with our own. The only American republics in addition to the United States which lie wholly or mainly within the temperate zone are Argentina, Chile, Uruguay, and Paraguay, the others being mostly tropical or semitropical. With a large part of the tropical and semitropical areas still largely undeveloped, our agricultural imports from Latin America (which have constituted as much as $90 \%$ of our total imports from that area) have in the past been made up, to the extent of about $50 \%$, of commodities produced in this country. The leading product complementary to our economy which might be produced on a large scale in Latin America is rubber, of which there are indications of high-yielding strains in this hemisphere which may be able to offset some of the labor and other advantages of the Far East with its low-yielding strains. Ford in Brazil and Goodyear in Costa Rica and Panama are now producing rubber on a very small scale. Abaca, a tropical plant which supplies the Manila hemp of commerce, the raw material necessary for naval cordage for which no satisfactory substitute is known, has been grown principally by Japanese in the Philippines, but judging by a 2,000-acre planting in Panama, it could be produced satisfactorily in 
the American tropics. The cinchona plant, the source of quinine and native to South America, could probably be produced profitably in this hemisphere, whereas we are now dependent for supplies on the East Indies. Similar possibilities exist in other tropical plants yielding vegetable oils, drugs, perfumes, and flavoring extracts, in herbs, tropical fruits, and a number of hardwoods. In the mineral field, there are tin, tungsten, antimony, mercury, mica and other minerals not native to this country which we can import from South and Central America on a larger scale. From 1937 to 1939 our imports of rubber, quinine, cocoa, tea, tapioca, kapok, rotenone, fibers (sisal, henequen, and abaca), vegetable oils, cashew nuts, and natural silk averaged annually about a half billion dollars, most of which came from Asia, and of which only $6 \%$ originated in Latin America. Most of these products could be grown in Latin America in much greater quantity than at present. As has already been indicated, there is a major question of long-term over-all expediency as to the extent to which such production should be developed at the possible expense of older sources of supply. In addition to jute, flax, and hemp substitutes and some of the other articles mentioned above, importers in this country are showing increasing interest in Latin American glassware and earthenware, handicraft and native food products, all of which offer considerable longer-term developmental possibilities.

2. Industrialization. At the present time, agricultural rather than industrial development is more feasible because the former is more suited to our needs and, more important, would require a smaller export of capital goods from this country. Furthermore, for an indeterminate period, South and Central America, as has been true of most areas in an early stage of industrial development, will be able to import most manufactured goods more cheaply than they can produce them, owing to various fundamental factors, such as lack of coal, poor transportation facilities, less effective labor supply, small markets, and lack of standardized technique. Over the longer term, however, a greater degree of industrialization of the different American republics is desirable, to raise their standard of living, diversify their economies, save needed exchange, and increase their over-all buying power. Our own commerce is normally greatest, not with undeveloped raw material producers, but with our industrialized competitors such as Great Britain, Germany, France and Canada. With certain exceptions such as Brazilian steel, near-term efforts toward industrialization of the other American republics should be directed not toward capital goods industries, many of which would prove uneconomical, but toward consumer goods industries, such as shoes, shirts, soap, foodstuffs and the like.

Many of our manufactured goods are too high priced for the pocketbooks of the average South and Central American. Germany and Japan, on the other hand, have exploited the low-priced field. Consumer goods industries, to be successful in most of Latin America, would have to be principally in the low-priced field and would therefore not compete with our own manufacturers to any great extent. It has been suggested that our manufacturers must enter the low-priced field to a much greater extent in order to build up a substantial trade with most of the American republics; 
also, since the price factor looms so large, that our exports should be subsidized to compete in those countries.

Development of new industries based on substitutes holds considerable promise. Corn can be used for the manufacture of alcohol and other products, while it is possible that coffee can be made a source of chemicals. Changes of this type offer many other opportunities. In addition, the replacement of war materials used in consumer goods with other available materials, a phenomenon increasingly evident in the United States owing to the priorities situation, may offer some possibilities for the development of new industries in the other American countries as well as here. Aluminum and stainless steel are giving way here to wood, glass, porcelain and enamelware, silk to other fibers and synthetics, tin cans to glass and paper containers, and so on. Industrial and government laboratories are engaged in research along these lines. Since Latin America has no research laboratories comparable to our own, any information which we pass on to them concerning substitutes may not only help them solve their urgent immediate problems occasioned by our priorities program, but also lay the foundation for new and profitable industry on their part.

Through an Export-Import Bank credit of $\$ 20$ million, Brazil is now building a steel plant, which will put Brazilians to work producing Brazilian iron ore, manganese, and coke, as well as making iron and steel (with a saving in ocean freight), which in turn will stimulate other Brazilian industries. Another step toward the development of new industry has been taken with the aid of the Inter-American Development Commission and the collaboration of the United States wholesale and retail trade. Studies have been made of retail store merchandise which might be produced in the other American republics to replace similar articles formerly imported from Europe, retailers have visited those countries, and an import business along these lines has already begun. Such merchandise includes handicraft and manufactured articles of a wide variety (glassware, earthenware, silverware, toys, novelties, hand-hooked and rag rugs, leather goods, and so on).

Potentially important in the field of industrialization over the longer term is the inter-American trade scholarship program of the Office of the Coordinator of InterAmerican Affairs. This program will start bringing to this country early in I942 carefully selected young South and Central Americans who will be apprenticed in many of our industries and learn United States methods and techniques.

3. Technical help. One of the most obvious ways in which we can promote our long-term objectives is by providing technical aid to the other American governments. North American technical experience and ability is very much in demand in South and Central America and meets with an enthusiastic reception. Some examples of technical help already extended in agriculture, mining, fisheries, and a variety of other fields are presented in the succeeding article in this symposium.

4. Stimulation of trade. Increased trade among the other American republics themselves is an important objective, particularly since such trade accounted for not more than $10 \%$ of their total trade prior to the war. The greater the diversification 
which those countries achieve, the larger will be the potentialities for successful trade with one another. Trade agreements have already been worked out between a number of the other American republics, such as those between Argentina and Brazil and between Brazil and Colombia. Since transportation difficulties present many natural obstacles to such trade, our help can be extended in this field by technical aid to the governments of the other republics in road construction (as has been done already in a number of cases) and by loans such as those made to certain countries to help them complete their sections of the Pan American Highway. Other roads besides the Highway will be needed for this inter-Latin American trade.

In addition, a larger and soundly balanced trade between ourselves and the other American republics is one of the prerequisites to Pan American solidarity. Over the longer term, we must accept a larger import balance in goods and services to enable them to service their debt to us while buying more from us. As the development of the many products mentioned above proceeds, the greater should be the demand in this country for imports from the south. In solving the problem of buying more from them without too much disturbance of our own economy, the broader national interest may come in temporary conflict with that of local groups. The Hull trade agreements program, now including more than half of the other American republics, should be continued. Liberalization of credit terms of United States exporters over the longer term may be desirable. The credit plan announced by the Export-Import Bank in October to alleviate the hardships on Latin American importers caused by the wartime demands of some of our exporters for cash long before delivery, is an example of effective collaboration in this sphere. The success of the German and English traders in Latin America has been partly due to their greater willingness to assume risks. The emergency offers our exporters a chance to enlarge permanently their share of the market if they cultivate it intensively, study it at first hand, develop loyal distributors, and maintain field representatives in sufficient number who will take the trouble to learn the language and customs and will not be withdrawn as soon as the emergency passes.

5. Tourist travel. A permanently increased tourist travel to the other American republics will also be effective in creating dollar exchange for them. Finances of most South and Central American countries have been strained by a more or less permanent shortage of foreign exchange (temporarily alleviated by aid which we extended at the outset of the war and by our subsequent inability to provide them with all the goods which they need from us). A thriving tourist industry would be a boon to their economies in its own right. Before the war United States tourists were spending annually about $\$ 220$ million in Europe and only some $\$ 60$ million in Latin America. Much improvement is needed in hotels, transportation, and other travel facilities in South and Central America. Reduction in the cost of travel between this country and South America must also receive serious attention.

6. Commodity collaboration. Commodity collaboration directed particularly against disastrous marketing conditions is another area of useful cooperation. A subcommittee of the Inter-American Financial and Economic Advisory Committee has 
been studying the surplus problem in coffee, cotton, cacao, and other staples. The Inter-American Coffee Agreement, which was drafted by this Committee with the close cooperation of the United States coffee industry, signed by the participants in November, 1940, and subsequently approved by Congress, prevented a collapse in the coffee price structure through the allotment of quotas for the import of coffee into this country from the fourteen American producing countries. Selling cartels and other schemes have been propounded to solve the very thorny surplus problem. While proper development and diversification of Latin American economies, with the resultant increase in purchasing power, will help to alleviate this problem in the long run, more effective inter-American commodity collaboration is needed to relieve one of the greatest strains on sound hemisphere relations.

7. Capital investment. How will the expansion and diversification of Latin American primary production and industry be financed? The sources of capital within the countries themselves are very limited. The influx of private capital on a sound basis would be highly desirable, but United States private capital has been made wary by the record of many Latin American dollar bonds, as well as by occasional cases of expropriation. As of December 3r, I940, of the almost \$I billion par value of United States holdings of bonds of the other American republics (including corporate issues), $63 \%$ were in partial or complete default, as compared with $59 \%$ of European issues and $3 \mathrm{r} \%$ of total foreign dollar bonds held in this country. While the service charges were often too great in relation to the finances of the debtors and while our restrictions against imports helped to prevent repayment, there were also instances of bad faith on the part of some Latin American debtors. Some sort of settlement of the debt situation must be reached to pave the way for future investment on a more careful and realistic basis than in the past; such a settlement is essential to sound inter-American relations over the longer term. Another unfortunate feature of Latin American financial history has been the tendency of Latin Americans themselves to invest abroad rather than in their own countries. Joint capital ventures combining local with United States capital would tend to make our capital less of a target for local politicians in the country in question; whenever possible participation of local capital should be secured. For the time being, substantial capital investment will have to be done by government; this is being done by the Export-Import Bank, which is making loans at low interest rates and scrutinizing its loan applications very carefully. It is interesting to note that of the $\$ 558$ million of credits extended to Latin America by the Bank from its establishment on February I2, 1934, up to November 30, x94I, only $\$ 125$ million has been disbursed and $\$ 74$ million $(60 \%)$ of this has been repaid. There has not been a single instance of default on service charges or principal repayment to date. In general, those countries are understandably wary of losing control of their own affairs, and loans by us should therefore be directed toward aiding them to carry out constructive development which they want and of which they would retain control.

8. Social programs. Important in any long-range developmental plans for the other American republics are social programs to improve the health and producing 
power of the people. In many areas illiteracy, malnutrition, and disease are prevalent. Much has been done through the Rockefeller Foundation and other private and public agencies, particularly toward the elimination of disease; much more remains to be done. Improved low-cost housing and sanitation projects might be financed by this government at low interest rates. Resettlement and colonization possibilities provide another important and potentially large area of possible action.

\section{IV}

What is the machinery, international and national, through which our economic objectives may be attained?

In September, 1939, after war had broken out, the Foreign Ministers of the 2I American republics met in Panama to discuss joint measures that might be adopted in view of the threat to hemisphere security. At that conference there was created an Inter-American Financial and Economic Advisory Committee, of which Mr. Sumner Welles is Chairman and which is composed of one expert in economic problems from each country, to sit continuously in Washington for the duration of the war and recommend measures for meeting special economic problems caused by the war. Besides working on shipping problems, commercial relations, and so on, this Committee was instrumental in arranging the Inter-American Coffee Agreement, drew up the convention and by-laws of an Inter-American Bank, and created the Inter-American Development Commission.

The Inter-American Development Commission, formally organized in June, 1940, is one of the most promising media for constructive developmental work and effective international collaboration yet established. It is a permanent international body, with the Coordinator of Inter-American Affairs as Chairman and the other four Commissioners, all resident in this country, being of Brazilian, Chilean, Costa Rican, and United States nationality. The Commission has meetings from time to time and has a small staff recruited from the Office of the Coordinator of Inter-American Affairs. Sub-commissions have been formed in each of the other American republics, composed of five nationals of those countries who are leading representatives of industry, finance, agriculture and mining, transportation, and government. These sub-commissions provide an excellent means of carrying out developmental projects in those countries and submit their ideas and plans as to desirable projects to the headquarters of the Commission in Washington. The Commission has been working to date particularly along the lines of stimulating increased production of noncompetitive products in the other republics and their export to the United States, the development of desirable industry, and diversification of economies. Its scope includes the preparation of basic studies and establishment of contacts among capital, technicians, management, and government to promote the initiation of sound projects. The Commission has established a Merchandising Advisory Service in New York which advises Latin American exporters in the adaptation of their products and marketing practices to our markets and helps our importers locate sources of supply in the other republics. Joint use of Latin and North American capital is stressed. 
The proposed Inter-American Bank, discussed periodically at inter-American conferences, seems now much closer to actuality as a result of the work done by the Inter-American Financial and Economic Advisory Committee. The convention of the Bank, already signed by most of the American republics, must be ratified by their respective legislative bodies. Such legislation is now pending before the United States Congress. This Bank, a sort of Inter-American Bank for International Settlements, is not intended to encroach on adequate existing banking facilities, but may be useful in providing financing not in the sphere of private banking as well as a meeting ground where the financial minds of the American republics may solve mutual problems. Perhaps some additional private inter-American financing agency may be found desirable at a later date. It is hoped that the Inter-American Bank will not only come into being but will aid in the development of a hemisphere system of strong central banks and sound currencies.

Finally, future inter-American agricultural cooperation should be facilitated by the proposed Institute of Tropical Agriculture, to be established in one of the other republics. The Institute would conduct research, train personnel, and provide a meeting ground for agricultural students and experts from North and South.

When it comes to machinery in this country for promoting our objectives, the Department of State is the key agency. The Department of Commerce has also had to do with our inter-American relations for a great many years and can therefore offer invaluable assistance in this field. The Department of Agriculture, the Bureau of Mines, the Fish and Wildlife Service, and the Public Roads Administration can provide or obtain necessary trained personnel for Latin American work, a field in which they have long been active. The Treasury Department is interested through its Stabilization Fund, its membership on the Export-Import Bank directorate, and its relationship to the dollar bond and other inter-American financial problems.

The Export-Import Bank of Washington, established by our government in 1934, has in recent years assumed a major role in inter-American affairs, particularly since September, I940, when Congress authorized an increase in the Bank's capital from $\$ 200$ million to $\$ 700$ million, "to assist in the development of the resources, the stabilization of the economies, and the orderly marketing of the products of the countries of the Western Hemisphere." Other government departments and agencies, as well as private groups, are also concerned with various aspects of inter-American affairs.

The Office of the Coordinator of Inter-American Affairs was created in August, I940, to coordinate the activities of these and other departments and agencies in the field of inter-American affairs and to provide additional facilities where existing agencies might not be immediately prepared to undertake certain types of work. The Coordinator, Mr. Nelson A. Rockefeller, was recently appointed a member of the Board of Economic Warfare, and the staff of the Board charged with work in the inter-American field was merged with the Commercial and Financial Division of the Coordinator's Office to form the American Hemisphere Division of the Board. Long- 
term plans for increased production of defense materials and strengthening of the economy of the other American republics form part of the work of the Board.

Another aspect of the defense program should be mentioned: the distribution of Lease-Lend aid to Haiti, Chile, Uruguay, and Brazil, with other countries to follow. Such aid, while primarily for defense, may play an important role in the future economic development of the recipients.

\section{V.}

In any long-term economic program involving such a huge area, the question naturally arises where one should begin. In this case, a substantial beginning has already been made. Should the emphasis be on solving immediate problems as they arise, on dealing with many problems in certain countries, or certain problems in all the countries? There can be no categorical answer to these questions, but they are being solved on the basis of accumulated experience, as well as of comprehensive studies of the economies of each country which have been and are being made, and information and advice from the countries themselves and from our own representatives in the field.

It is becoming increasingly evident that the rapidly accumulating knowledge of and experience in problems affecting all the American republics should continue to be put to work in the interests of this government and hemisphere when the war is over. Not only should increased inter-American trade be continued and expanded, but we should also follow up every line of activity which will strengthen the economies of each country and hence of ourselves. Aside from most of the problems already discussed which we are meeting at the present time, there will be the major problem of cushioning the shock on inter-American economies and trade of the potential let down in war-stimulated primary and industrial production. We will have been partly responsible for many of the difficulties in which they may find themselves; it will therefore be partly up to us to help them out.

Latin America is more and more becoming the focus of all this country's long-term economic planning. Major problems remain unsolved, but a beginning has been made and a line of approach formulated. A surprising amount of tangible good has been accomplished since the first attempts at economic implementation of the Good Neighbor policy, particularly when one considers how little had previously been accomplished in this field. Proportionally, however, the surface has barely been scratched.

The time, money, and man hours that we are spending on this work are not spent for the purpose of tying other nations to the control of our political or financial policies. Our purpose is to help create a group of strong nations to the south of us for the lasting improvement of their prosperity and ours, to give them a brighter economic and social future to live and fight for against totalitarian aggression. We are engaged in an attempt to solve international economic problems in a spirit of common sense and cooperation, having as its major premise the desire to assist economic and social life in all twenty-one of the American republics. 